CORRECTION

\title{
Correction: Defective chromatin architectures in embryonic stem cells derived from somatic cell nuclear transfer impair their differentiation potentials
}

Dan-Ya Wu, Xinxin Li, Qiao-Ran Sun, Cheng-Li Dou, Tian Xu, Hainan He, Han Luo, Haitao Fu iD, Guo-Wei Bu, Bingbing Luo, Xia Zhang, Bin-Guang Ma, Cheng Peng (iD) and Yi-Liang Miao (iD)

(c) The Author(s) 2021

Cell Death and Disease (2021)12:1132; https://doi.org/10.1038/s41419-021-04426-9

Correction to: Cell Death and Disease https://doi.org/10.1038/ s41419-021-04384-2, published online 16 November 2021

The original version of this article unfortunately contained a mistake in an author affiliation. The correct affiliation of Xinxin Li is Hubei Key Laboratory of Agricultural Bioinformatics, College of Informatics, Huazhong Agricultural University, 430070 Wuhan, Hubei, China. The original article has been corrected.

\begin{abstract}
Open Access This article is licensed under a Creative Commons Attribution 4.0 International License, which permits use, sharing, adaptation, distribution and reproduction in any medium or format, as long as you give appropriate credit to the original author(s) and the source, provide a link to the Creative Commons license, and indicate if changes were made. The images or other third party material in this article are included in the article's Creative Commons license, unless indicated otherwise in a credit line to the material. If material is not included in the article's Creative Commons license and your intended use is not permitted by statutory regulation or exceeds the permitted use, you will need to obtain permission directly from the copyright holder. To view a copy of this license, visit http://creativecommons. org/licenses/by/4.0/.
\end{abstract}

(c) The Author(s) 2021 